\title{
Reconciling Sustainability Issues and Urban Policy Levers
}

\author{
Nicolas Bricas, Christophe-Toussaint Soulard, and Clément Arnal
}

The development of urban food policies is not based on unified approaches. This policymaking process is relatively recent and there is still insufficient hindsight for the development of approaches that could encompass the complexity of food systems. In the previous chapters we have seen that many initiatives are under way around the world, taking very different approaches. Hence, research needs to focus on how to design such policies, and tailored methods are beginning to be formalized. As was shown in chapter "Theoretical Approaches for Effective Sustainable Urban Food Policymaking", some methods are based on the food supply system or value chain, and look at urban systems through that prism, whereas others build on a certain conception of the urban system and attempt to integrate agricultural and food considerations into urban sustainability scenarios. In either case, the knowledge that must be leveraged is multifarious and difficult to formalize. So great are the resulting uncertainties that the more general question arises as to the value of expertise in urban food policy making - a question already current with respect to environmental policies (Lascoumes 2010). While the players must clearly rely on evidence in order to decide and take action, they are confronted with a bewildering array of areas of endeavour, given the need to reconcile complex urban and food systems with sustainability issues.

In practice, we see that stakeholders are often not fully aware of that complexity when taking action or measures and are hence unable to predict all of the impacts on the various dimensions of sustainability. As the effects of their actions cannot be accurately foretold, they follow their intuition. Failures and partial misfires may result, but also successes and cases of systemic leverage. As this book has pointed

\footnotetext{
N. Bricas $(\square)$

UMR MOÏSA, Cirad, MONTPELLIER CEDEX 5, France

e-mail: nicolas.bricas@cirad.fr

C.-T. Soulard · C. Arnal

UMR Innovation, Montpellier University, INRA, CIRAD, Montpellier Supagro,

Montpellier, France 
out, city dwellers take many different initiatives, individually or in more or less formal organizations, seeking to overcome the constraints and limits of urban life.

To pay more heed to these initiatives, as is proposed by advocates of social practice theory, is not without political consequences. That theory suggests that public policies aimed at changing the impact of consumption on health or the environment should target practices and the environment that determines them rather than individuals and their knowledge and attitudes (Warde 2005). Similarly, it holds that the cumulative effect of changes in customary practices will bring systemic and institutional changes (Shove et al. 2012). In the urban food system context, as shown in chapter "Theoretical Approaches for Effective Sustainable Urban Food Policymaking", social practice theory would dictate that urban food strategies should be developed and consolidated synergistically, through a multiplicity of micro-initiatives (Cohen and Illieva 2015). Policies are no longer to be developed in isolation, without input from the citizens engaged in these initiatives, but rather based on citizens' practices and the transformative effects thereof.

Keeping in mind that desired manner of designing urban food policies, in this chapter we propose a conceptual framework under which cities' public actors will be better able to devise, manage and evaluate their food policies, or in other words to target and synergize the actions they take and assess their outcomes. These public actors, which we refer to as local urban governments (LUGs), are of course not the only stakeholders in the food system. They work alongside business and civil society, but we conceptualize their role as that of an enabler within the urban food system, able to spur these other actors to action or synergize them. The idea then is not to consider these local public actors in isolation, but to provide them with the tools they need, firstly, to enhance actions for which they could provide impetus via their expertise, and secondly to enhance their intermediary role vis-à-vis the other actors in urban food governance: the market and civil society (Viljoen and Wiskerke 2012). From that point of view, the food system sustainability issue is not solely concerned with the nature and effects of the actions taken, but also with the relevant policies' modes of governance (Brunori 2015). That duality is specifically illustrated in the account of the development of an urban food policy presented in chapter "Putting Food on the Regional Policy Agenda in Montpellier, France".

While chapter "Urbanization Issues Affecting Food System Sustainability" set out an analytical framework for urban food system sustainability, what we propose to explore here is an area that has been little studied in the literature: the means of action and leverage available to LUGs. Most approaches to the development of urban food policies call for a preliminary objective assessment of the urban food system to be addressed and identification of the problems to be solved. But such approaches seldom take the realistic scope of action of LUGs into account. Leverage, however, is another frequent consideration in their endeavours. The first part of this chapter deals with the various forms such leverage can take. Sustainability issues can be jointly plotted for comparative purposes on a double-entry matrix. Each lever being used can thus be assessed in terms of food system sustainability issues or, moving to the other side of the matrix, the different levers available to act on a given problem can be examined. 
Urban food policies can then be developed through a back-and-forth between the identified problems and possible levers. The different ways of devising urban food policies will be analysed in the second part of this chapter.

\section{Local Urban Governments' Scope of Action}

Cities' renewed interest in the food issue is being expressed in the dual context of globalization and decentralization. LUGs are seeing a change in their jurisdiction and an increase in their powers, as evidenced for example by the implementation of territorial food projects (PATs) in France or Local Food Promotion Programs (LFPPs) in the United States. However, the degree to which State powers are decentralized to more local levels is very variable by country and often evolving in both respects, jurisdiction and scope of authority. In identifying the levers available to LUGs we do not mean to imply that all can always be deployed by all. Moreover, the typology proposed in this chapter is intended as a basis for reflection and needs to be adapted to each institutional and political situation.

\section{Definition of Levers}

In order to explore the levers available to LUGs, we propose to begin with the capacity for action that States endow them with: economic development, social, education or health policy, etc. To identify these levers, we looked at the internal organization of LUGs (administrative divisions, etc.) using the organization charts of a sample of world cities and conurbations for which that information was available. ${ }^{1}$

To be clear, we must differentiate these levers from the instruments, procedures or means available to an LUG to wield a lever. A 'lever' is defined as an LUG purview or area of activity. Spatial planning would be one example: an area of activity for which one or more initial objectives have been defined, for example the people's wellbeing, inequality reduction, or economic development. To achieve these objectives, the LUG has instruments of its own, such as its local urban plans (Plan Local d'Urbanisme, PLU), territorial coherence planning (Schéma de Cohérence Territoriale, SCoT), etc., in the case of France, and its own investment capacity. For a PLU or a SCoT, these instruments are based on various procedures: assessment, initial environmental state, sustainable planning and development plan (Plan d'Aménagement et de Développement Durable, PADD), orientation and objectives

\footnotetext{
${ }^{1}$ Cities and conurbations in France (Lyon, Lille, Bordeaux, Nantes, Montpellier, Annecy, Bourgen-Bresse, Romans-sur-Isère, Alençon, Angoulême), in North America (Toronto, Quebec City, Montreal, New York City), in Europe (Lausanne, Geneva, Brussels, Liège, Bristol, London, Munich), and in Africa (Niamey, Dakar, Marrakesh, Tunis).
} 


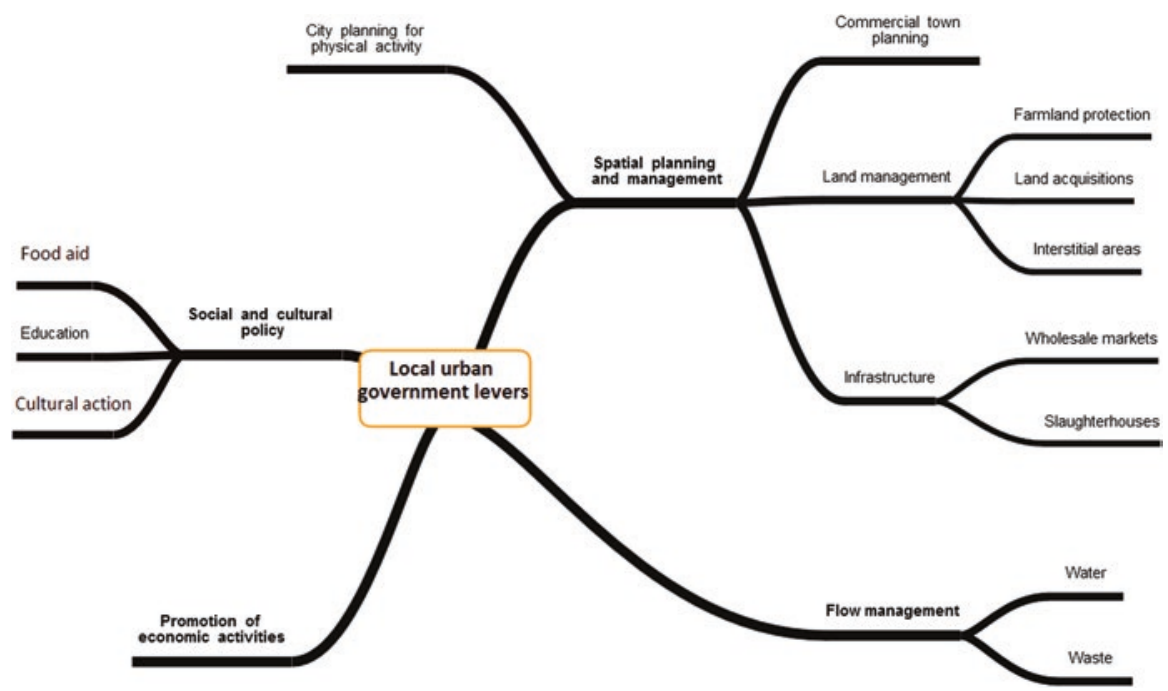

Fig. 1 Levers that local urban governments can deploy in support of agricultural and food policies

document (DOO), regulations, etc. Finally, LUGs have the human, technical or financial resources available to the units responsible for a lever or the use of an instrument. A lever-seen as an area of activity-thus possesses its own instruments, tools, procedures and means.

At an international conference that we held in Montpellier, ${ }^{2}$ bringing together numerous Latin American, African and Asian cities that had implemented agricultural and/or food policies, we identified various levers used by them to ensure food security and improve popular nutrition or, more generally, to improve food system sustainability. Following that meeting we held a workshop with urban food systems experts at which we developed a typology of these levers and past and current objectives assigned to them. ${ }^{3}$ As we discovered, those objectives have changed over time as new concerns emerge.

The main levers identified during this workshop are charted in Fig.1 and described in the following paragraphs.

\footnotetext{
${ }^{2}$ An international meeting on 'Urban Food Policies; markets, catering, rural/urban connexions' organized by the UNESCO Chair on World Food Systems, CIRAD, Agropolis Fondation, FAO, the French Development Agency, RUAF Foundation, ORU-Fogar, the Agence Universitaire de la Francophonie, the International Sustainability Unit and the Foundation for the Progress of Humankind, held from 16 to 18 November 2015 in Montpellier (France).

${ }^{3}$ Workshop participants on 14 December 2015 were: Clément Arnal (consultant), Nicolas Bricas (CIRAD, UMR MOISA), Damien Conaré (Chaire UNESCO AdM), Benoit Daviron (CIRAD, UMR MOISA), Julie Debru (UNESCO Chair), Florence Egal (consultant, Milan Pact), Anna Faucher (IUFN), Paule Moustier (CIRAD, UMR MOISA), Dominique Paturel (INRA, UMR Innovation), Coline Perrin (INRA, UMR Innovation), Christophe Soulard (INRA, UMR Innovation).
} 


\section{Spatial Planning and Management}

Cities are not exclusively built environments. They also include natural areas (forests, rivers, bodies of water and banks, etc.) as well as farmed or fallow land, in particular on the outskirts, whose future uses - maintenance or conversion-may be decided by LUGs. But built-up areas are also amenable to planning of alternate uses of 'free' areas or land uses related to urban projects: housing, infrastructure, shops, activities, etc.

Agricultural land needs to be protected from soil degradation and the leapfrog development associated with urban sprawl in order to maintain local agricultural production or create recreational or kitchen gardening areas, in particular for vulnerable populations. Several environmental objectives are fostered by these preservation efforts: biodiversity maintenance (green corridors), climate risk management (city cooling, buffer zones in case of flooding), greening of the city and creation of recreational areas and, lately, promotion of agricultural production for local food supply or even job creation. This farmland preservation may be done through regulation (see planning documents such as the local master plan or, in France, the territorial consistency plans (SCoTs), or farmland protection measures creating protected agricultural zones (ZAPs) and/or buffer zones around farmed and natural periurban land) and/or land acquisitions or rights of first refusal.

Some municipalities may acquire land well beyond their territorial limits, and in some cases have done so since ancient times. Lausanne, for example, owns eight farmsteads and some one hundred individual lots totalling about 900 ha. While all of this land was formerly leased out and worked independently of the city, Lausanne's new food policy has sought to take advantage of the land base to supply school canteens and develop educational farms as green technology showcases. The city's new agricultural policy also helps forge closer relations between town and country (Jarrige 2013).

On a finer scale, town planning regulations play on habitat density and the size and use of private plots. The choices made then determine the possibilities of cultivated gardens and domestic or shared orchards and hence food self-production. Similarly, marginal areas_fallow land, public gardens, schoolyards, sidewalks, vacant lots, building roofs - can be used for gardening, fruit production and animal husbandry (bees, hens), as a means of encouraging urban agriculture. Among the possible goals are: to provide access to sources of additional food or income under social policies, to create leisure areas or meeting places through gardening, to create places where people — and in particular children — can be introduced and sensitized to agriculture, to enhance management of the environment and livelihoods, and to promote health-giving physical activity. On this last point, designing town planning to facilitate physical activity can significantly improve people's nutritional status, particularly those who consume excess calories, through the provision of cycle paths, fitness trails and sports areas (Yin et al. 2013; Epstein et al. 2012; Raja et al. 2010).

When it comes to commercial town planning, LUGs can to a great degree dictate the location of food shops, markets and eateries. The food landscape is greatly affected by the establishment of malls on the outskirts or, conversely, the development of 
neighbourhood retail marketplaces — often for reasons of sanitation-and permanent or floating eateries (e.g. food trucks), all of which also makes a difference to how far households need to go for food supplies and to whether certain products are consumed as they become more or less accessible. Where no policy exists on food shop location, there is a danger that 'food deserts' will appear where it becomes difficult or expensive to easily find quality food, in particular fruit and vegetables. The reorientation of commercial town planning to prevent food deserts has become a concern for very many North American cities.

\section{Flow Management}

Substantial flows of food and water are needed to supply cities, which export their production and send their waste the other way. Everything that is consumed, recycled and discarded is affected by the management of these flows.

Wholesale market management, though initially concerned with the logistics of the flow of food into cities, can serve to connect or reconnect them to local farmers. City administrations that manage these wholesale markets can set aside specific direct sales areas to which small-scale producers, not just wholesale dealers, will have access. That is one priority for these markets, given the development of retail logistics that tend to reduce the number of reference products marketed and hence product diversity. Where the wholesale markets are sited, how producers access them, and how they interface with retail stores or markets are all determining factors for the conurbation's relationship with its hinterland. Proactive actions can encourage certain forms of agriculture by opening up the urban market to farms too small for the usual retail channels or by setting aside areas reserved for organic farmers.

The creation and management of municipal slaughterhouses on the outskirts of town generally serves a public health purpose: to eliminate the risks involved in having livestock within densely populated areas and to monitor the health of slaughter animals. In addition, they give nearby farms access to the urban market and favour the development of businesses to process meat, hides, horns and other byproducts. Slaughterhouses also give structure to the economic organization of livestock industries.

City administrations often have jurisdiction over the provision of drinking water. In developing countries, that has a direct effect on nutrition in that it prevents infectious digestive diseases that are largely responsible for diarrhoea and hence childhood malnutrition. In industrialized countries where groundwater is polluted by agriculture chemicals, LUGs can acquire land within watersheds (e.g. Munich, New York) to ensure that it is not polluted, or give incentives to farmers operating within the catchment area to switch to organic farming in exchange for guaranteed outlets for the food they produce, to supply school cafeterias or municipal establishments (e.g. Munich, Lons de Saunier) (Le Strat 2008; Hellec et al. 2013). In that way cities can play an incentive role with respect to agricultural production conditions in areas outside their direct span of control. 
Similarly, some LUGs contract with producers even in relatively remote rural areas to ensure quality food supplies. In exchange for a commitment to selling their produce to the city, LUG services can then advise them and even promote investment in the rural areas concerned. The municipality of Hanoi in Vietnam negotiates such contractual relations with 52 of the country's rural provinces in order to ensure a supply of good-quality, healthy products, thus contributing to the provinces' rural and agricultural development.

Urban waste management, for organic waste in particular, is essentially intended as a sanitary measure but can also serve to recycle organic waste into green manure, which, when used in agriculture, restores the nitrogen and phosphorus cycles broken by the use of chemical fertilizers. The distribution of poultry to inhabitants, or subsidies for henhouses provided by some municipalities, has the same objectives: reduction of urban organic waste by recycling, and promoting egg production.

\section{Promotion of Economic Activities}

Most LUGs seek to encourage or sustain economic activities that generate employment or income for the people, but also sources of tax revenue. They do so in a number of ways, creating areas for companies to set up (business zones, transport infrastructure connexions, clustering of research and innovation institutions, etc.), lending or leasing premises cheaply, adjusting business tax regimes (duty-free zones), organizing networks and services, etc. Food processing and distribution sectors, as well as catering, provide significant numbers of jobs, in particular in developing countries, where micro- and small businesses are the norm (Broutin and Bricas 2006). A number of objectives are pursued in supporting these sectors: job creation, particularly for women, often the majority in this industry; access to food for populations with little purchasing power; and even enhancement of gastronomic heritage that can help boost a tourism development policy. In European countries, some LUGs promote the development of social and solidarity economy businesses.

A characteristic form of economic stimulus involves the commercial promotion of specific products of an area, often with a view to tourism promotion, for example in the form of a special accreditation or local brand. That leverage can however also be used to foster greater connexion between the city and the countryside. For example, the municipality of Montpellier has set up a series of summer events to promote gastronomic products and specialties of the surrounding countryside to the urban population.

\section{Social and Cultural Policy}

Leverage is also frequently applied through the city's social policy, in particular as regards food aid for the most vulnerable populations. 
Thus, municipal centres for social action (CCASs) distribute some of France's food aid and can assist the poorest residents with food vouchers or coupons or by paying part of the cost of children's school meals, meals on wheels for the elderly, etc.

Other food supply actions may be taken to promote the integration of certain population groups. One example is the provision of public land for people fleeing conflicts, as in Bogotá, or the creation of farmsteads by people in the process of social reintegration.

Service to the people is one lever frequently used, in particular with respect to catering, whether for children (cafeterias at schools, nurseries or recreation centres), the elderly (nursing home cafeterias, soup kitchens, meals on wheels) or vulnerable populations in general. The initial purpose of school meals has often been to encourage parents to send children to school, but they have become an assurance of food security for all, in particular in dire inequality and poverty situations. In Latin America, many cities are implementing ambitious social policies through catering, for both children and adults. The idea is not just to provide everyone, even the poorest, with a balanced meal; those who supply the school meals may, as in Brazil, be recruited exclusively from among local family farmers, thereby extending the reach of the city's social policy into the countrysides that supply it. Brazil's pioneering municipal policy on food security, in Belo Horizonte, served as a model for the Lula Government's national 'Zero Hunger' policy (Rocha 2001).

In some countries, school meals are also a means of integrating the population in social and cultural terms (Pinson 1995). Repeated sharing of the same meal at school is an integrating factor. It may however also be divisive, as is evidenced by contemporary debates on cafeteria menus with or without pork, or without any meat. There are many priorities for school meals today: improved nutrition, taste and nutrition education, learning how to fight waste, awareness of agriculture thanks to school gardens, promotion of green agricultural systems (use of organic farming products), or relocation of sources of supply.

The last-named objective is now very common in industrialized countries' urban food policies. It reflects a strong demand for proximity, both geographic and organizational, among city dwellers who are concerned with the remoteness of their relationship with agriculture and food (Chapter "Urbanization Issues Affecting Food System Sustainability") as well as the new risks associated with food system industrialization (chemical use, food artificialization, concentration of power and financialization of business, etc.).

LUGs may have public health responsibilities and apply risk prevention measures, food hygiene controls, etc. French communes, for example, have a 'hygiene' unit that comes under mayors' policing authority and may exert control over food businesses, restaurants and open-air markets, to ensure that the food provided to consumers is safe. This involves checking that food storage temperatures are complied with, that the establishments monitored are generally clean, and that staff have training in hygiene, proper attire, etc. In some cases municipalities may enter into local health contracts, under the auspices of the Ministry of Health, to be able to implement more ambitious monitoring and prevention policies.

Finally, the field of food supply may be affected by cultural policies, which may seek to take advantage of a historical heritage, or even forge an urban identity 
through food. They may also seek to promote mutual awareness among communities of different sociocultural origins through culinary exchanges, neighbourhood meals or 'discovery menus' in school catering.

\section{Evaluating Leverage in Terms of Sustainability Issues}

Again, using this inventory, sustainability issues can be jointly plotted with the leverage available to LUGs on a double-entry matrix, which can be used either to ascertain what types of leverage could be applied to a given food issue, or to look into what types of issue a given type of leverage might be suited to.

A matrix such as this would also raise a series of research questions about the leverage available on the different sustainability dimensions involved. As pointed out above, many of the existing levers were devised to deal with issues other than those covered by the promotion of more sustainable food systems. There are still a large number of very open-ended research questions. For example, how do we evaluate what effect it will have on the environment, on the sustainability of agricultural production patterns, on job creation, and on city dwellers' relationship with agriculture, to keep agriculture going in or around the city? Again, how can we evaluate the effects on food practices and representations of an urban food environment, and in particular commercial town planning or the offer of garden plots? How can we evaluate catering actions' effects on nutrition or intercultural dialogue? And finally, how can we evaluate the effects of food supply relocation on the environment, nutrition, or social relations?

That is not to say that answering all of these questions is a prerequisite for the development of urban food policies. Such a matrix can nevertheless at least be used for discussion purposes and to highlight the relevance and potential impacts of the available levers via collective expertise. In practice, many political actions are decided on without any real certainty as to whether they will have the desired effect, even supposing the objective to be well defined. Food policies are rarely instituted on the basis of thorough knowledge of the effects and risks of the actions to be taken. Often, they simply follow on from former practice, by inertia, with ad hoc experiments that are then tailored to the circumstances. Hence, the actual conditions under which the policies are made need attention, which is the subject of the next part.

\section{Steps for the Construction of Urban Food Policies}

Given the many city initiatives to devise food policies, i.e. a coherent set of actions to improve food supply, some institutions have felt a need to propose conceptual and methodological frameworks for such policies (Chapter "Theoretical Approaches for Effective Sustainable Urban Food Policymaking"). The goal is often to try to put all the environmental, nutritional, economic, social, cultural and food issues into one framework, and all food system elements over which they hope to exert control: 
production, trade, catering, consumption, waste management and their various determinants. When such frameworks are developed the temptation is to urge LUGs to map their agricultural and food situation, while quantifying flows, surfaces, consumption, population; identifying and often locating all the players; listing corporate and citizen initiatives; and tracking changes for each of these elements. What makes this such a difficult exercise is the dispersal of the data, which are often kept by many different players, not necessarily working at the same scale (Brand 2015). Data may even be lacking for certain problem dimensions-one example is the environmental costs of food, a relatively new issue that has yet to be the focus of many statistical studies. It is time-consuming to do this kind of mapping and may be quite costly. It does often allow the importance of the various parts of the system to be gauged: how important urban food production is to consumption, what share of total employment agricultural and agrifood jobs account for, how serious food insecurity and nutritional diseases are, etc.; but often it has little direct usefulness in initiating actions.

The approach we advocate begins with the facts set out in the literature and observed in our practical research, namely that cities often take up the food issue for reasons other than an explicit intention to develop a sustainable food policy. There are certainly cases where that intention does exist, but it is not always, and in fact rarely is, the prime mover in current food policies. Instead, the issue arises because of other urban concerns such as health, hygiene, poverty, the environment, social movements, unemployment, etc.

In some cases, problems needing solutions will then focus attention on food, either directly (e.g. if a quality problem arises in school cafeterias), or indirectly, when food is one of the areas of activity in which solutions to a given problem may be found (to create jobs, for example, the food sector offers considerable scope for new activities).

In other cases, certain types of leverage can afford an opportunity to address urban food issues. While direct leverage is possible, through the creation of new, food-specific tools, the approach is also often indirect, as the food issue is addressed using tools originally designed for other purposes. Thus, cities have to manage waste, initially from the standpoint of health, but they then may seek to use the waste as fertilizer as an agroecological strategy in order to reduce waste storage and reprocessing needs. However, as we mentioned in the previous section, the potential for use of these means of action for food policy purposes is an area of knowledge that needs to be investigated.

\section{Toward Policymaking on the Urban Food Issue}

Starting with these three points of entry (policies, problems, levers), and the example of Bristol, where a food policy was formulated on the basis of an experience capitalization document (Carey 2011), we established a matrix of ways in which LUGs can address food: from policymaking approaches to the urban food issue. 
One approach is to begin with the levers available to LUGs. Given the great variety of perceived food problems, or a desire to regain some control over food supply but without any clear identification or formulation of the problems, a first step is to look at what can be done with the levers available. In that case, the action to be taken is arrived at not on the basis of an 'objective' assessment of the situation, indicating the objectives to be achieved, but rather of the levers LUGs can use to address food issues. That approach can be described as building a 'policy of means'. Few LUG officials have food expertise, but they are experts on the means they have available, and their predisposition is to use those means in addressing the new food supply area.

In our facilitation work with municipal officials in preparation for the agricultural and food policy of metropolitan Montpellier (Chapter "Putting Food on the Regional Policy Agenda in Montpellier, France"), we often noticed that mindset, namely that the officials thought about what those levers would allow them to do to achieve different goals than they were intended for. Thus, discussions took place around ideas such as using school cafeterias to promote organic farming in the region or hosting social and solidarity economy agrifood companies within the wholesale market.

A second approach is to begin with the specific problems LUGs need to solve. Those problems are not necessarily identified through a full assessment of the city's overall food situation, following which priority actions are mapped out. Instead, the problems are generally put on the political agenda by a few influential actors. In France, the fight against food waste has emerged as a problem to be solved not in the wake of any alarming assessment, but as a moral imperative, impelled by a number of actors who were able to mobilize politicians.

In our work with metropolitan Montpellier elected officials, we discussed the question of food insecurity, a particularly thorny one for them, with a view to identifying the levers the LUG could deploy against it: cafeteria prices, access to garden plots, food aid, support for solidarity groceries, etc.

The third approach is to start with a policy proposal, conceived of as a set of actions to remedy (and/or forestall) a set of food-related problems. That involves mapping out an action framework linking the problems to be addressed with the levers available to solve them.

These three approaches to urban food policies are summarized in Fig. 2.

In practice, these approaches will be combined, interlaced, or tried in sequence. The levers are scattered through different units of the LUG and the problems to be solved are varied and may be tackled by several of them. Some units will already

Fig. 2 Toward policymaking on the urban food issue

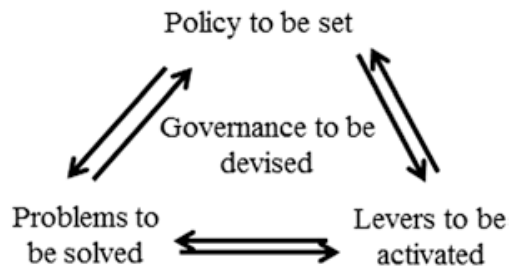


have set levers in motion when others get involved, acting on other concerns that may nevertheless have an impact on the first-comers' actions. Therefore, the construction or management of urban food policy is subject to considerable coordination and arbitration issues.

Another feature of urban food policies is that there are many initiatives and actions undertaken by civil society or the private sector that the LUG must seek a way to interact with. Hence our central focus, in this analytical framework, on the issue of food supply governance as a work in progress. That governance is indeed the central process, wherein policy choices, problems to be solved and levers to be pushed must be reconciled.

\section{An Iterative and Integrative Methodological Approach}

What consequences will such a conception of food supply policymaking have at the urban scale on support operations and research? In considering how to capitalize the support to be provided to metropolitan Montpellier's agroecology and food policy, the following three methodological principles may be proposed:

Principle No. 1: combine the three elements. The support to be provided is not a 'turnkey' operation. It will embody a procedure that combines the three elements to be included in food supply governance. While not in contradiction with existing approaches based on expert assessments, it will seek to integrate these into a comprehensive approach that will be fleshed out by the actors undertaking it, not laid down a priori by researchers or design offices.

Principle No. 2: provide tools for exploration of each element. Many kinds of knowledge will need to be generated to support urban food policies; using our design framework we can discern various types of assessments to perform.

- Problems: assessments to ascertain and understand them. Here, classic expert assessments will be needed in areas of food policy where the action that should be taken cannot proceed for lack of knowledge. Perhaps we have identified or are aware of a problem but its causes are poorly understood. In such a case an assessment establishing the causes or an investigation may make it clear how to proceed.

- Levers: assessments to control them. Such assessments are often lacking. While we may know how a given lever affects the problem it was designed for, it is much less clear how it will affect other problems, or what its systemic effects on food supply will be. What is needed in that case are assessments and joint innovation approaches that help actors to formalize work procedures that both take account of the objectives and embody suitable ways and means of acting. 
- Governance: assessments for positioning and evaluation. One requirement here is for models of the food system that can give actors an objective idea of the context in which their actions will be taken. For this purpose, the available outlines showing the various components of the food system and the issues involved, such as the one produced for metropolitan Montpellier, may be useful (Fig. 3). Another requirement, however, is to equip these actors with a way of evaluating the governance actually being undertaken by means of indicators of how far the objectives have been met and with what effects. Evaluation, so conceived, is the outcome of a learning process in which scientific knowledge and contextual knowledge are combined (Rey-Valette et al. 2014).

Principle No. 3: support governance. The international literature and our local experience (Chapter "Putting Food on the Regional Policy Agenda in Montpellier, France") teach us that urban food governance develops over the long term. Its objectives are ever-changing, the actors involved in achieving them change during the process, and the achievements and their knock-on effects bring about lasting readjustments. This kind of governance is adaptive and specific knowledge is required to direct it. Human and social science research can play a supporting role in the monitoring of governance, employing tools that 'map' the actors involved and, of these, those who are or are not 'enrolled' in the sociotechnical process (according to Michel Callon's sociology of translation 1986).

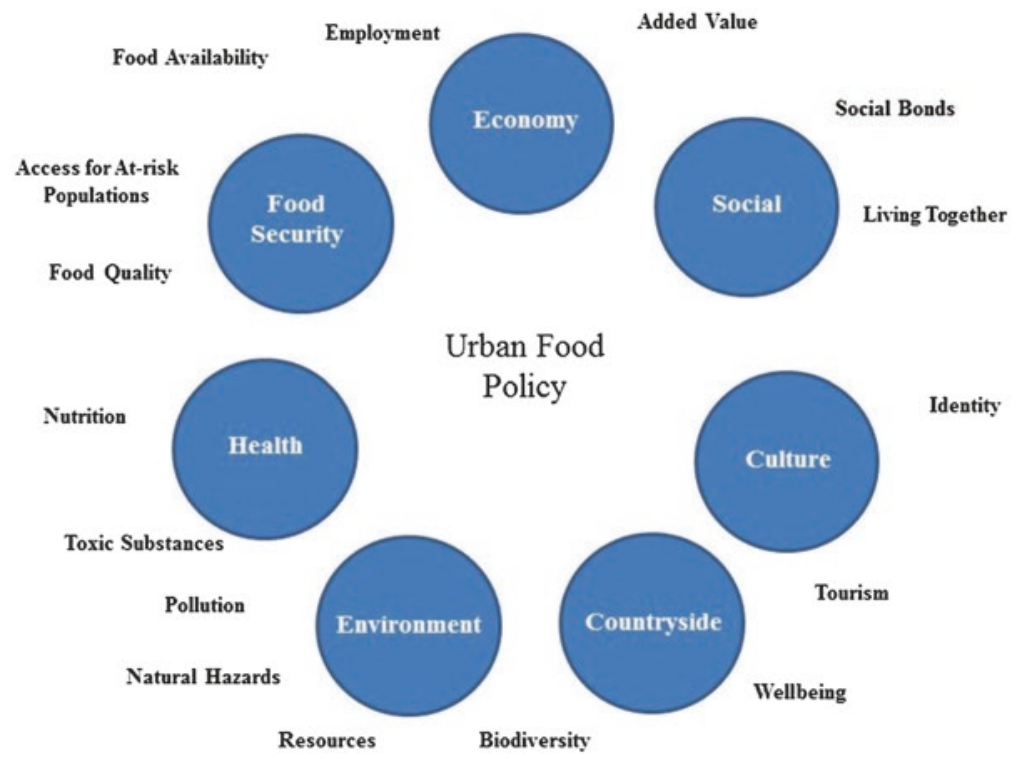

Fig. 3 An outline of the possible purviews of urban food policy 
A further requirement is for internal analyses of the strategies that players develop within organizations involved in governance (according to the 'sociology of organizations' of Philippe Bernoux et al. 2015).

The involvement of researchers in such processes implies that these flows of knowledge must not be seen only as reports of observations at a remove, but that interactions must be designed and directed throughout the public policymaking process. The design of procedures to support action research (Liu 1997) can be used to frame cooperative relationships between researchers and actual practitioners. Using such designs, the three research figures/postures may be combined to ensure a lasting partnership between researchers and actors on the ground (Soulard et al. 2007; Petit and Soulard 2015): expertise on targeted assessments, facilitation aimed at integrating disseminated knowledge during decision making, and the action of an evaluator seeking to endow the policy with an ongoing evaluation of the governance process.

\section{Conclusion}

What kind of conceptual framework can we develop that will cover at once the environmental problems posed by cities' food supply systems, nutritional problems or those occasioned by living together in the city? Rather than add one more new proposed scheme to the many that already exist, each of which seeks to map the complexity of urban food systems (Chapter "Theoretical Approaches for Effective Sustainable Urban Food Policymaking”), we resolved to explore an element that is little studied in the literature: the levers available to local urban governments to influence food supply. By identifying these levers and matching them with the food challenges caused by urbanization, we have been able to map certain research issues. In looking at each of the levers, we can investigate its real or potential effects on each of the potential problems to be solved. At that point, a specific conceptual framework needs to be developed for each of those issues. A study of the effects of commercial town planning on the sustainability of food practices cannot be done in the same context as one that looks into the effects of agricultural recycling of urban waste. Yet another framework will be needed to study the job creation impact of a food production relocation policy.

Accordingly, rather than propose an integrative scheme based on an expert's or planner's vision, we have sought to recognize the many different paths of policy development required by food issues. As we learned from our experience of supporting food policies, that approach can cater to actors from many different areas of activity, with often different and even divergent interests. If we as researchers are to 
support these actors in the construction of their policies, we need to acquire the ability to test the hypotheses that emerge at the interface of the new problems to be resolved and the levers available to them. Further, we need to cooperate with them to come up with new approaches suited to new challenges.

\section{References}

Bernoux P, Amblard H, Livian YF, Herreros G (2015) Les Nouvelles Approches sociologiques des organisations. Seuil

Brand C (2015) Alimentation et métropolisation: repenser le territoire à l'aune d'une problématique vitale oubliée. Doctoral thesis in Geography, Université de Grenoble, UMR Pacte, $656 \mathrm{p}$

Broutin C, Bricas N (2006) Agroalimentaire et lutte contre la pauvreté en Afrique subsaharienne. Éditions du Gret, Paris

Brunori G (2015) Alternative food networks as drivers of a food transition. In: Viljeon A, Bohn $\mathrm{K}$ (eds) Second nature urban agriculture. Designing productive cities. Routledge, Abingdon

Callon M (1986) Some elements of a sociology of translation: domestication of the scallops and the fishermen of St Brieuc Bay. In: Law J (ed) Power, action and belief: a new sociology of knowledge? Routledge, London

Carey J (2011) Who feeds Bristol? Towards a resilient food plan. Bristol Green Capital and Bristol City Council, Bristol

Cohen N, Ilieva RT (2015) Transitioning the food system: a strategic practice management approach for cities. Environ Innov Soc Trans 17:199-217

Epstein L, Raja S et al (2012) The built environment moderates effects of family-based childhood obesity treatment over 2 years. Ann Behav Med 44(2):248-258

Hellec F, Barataud F, Martin L (2013) Protection de l'eau et agriculture: une négociation au long cours. Natures Sciences Sociétés 2(21):190-199

Jarrige F (2013) The comeback of the food issue in the city of Lausanne: a challenge for the coherence of local policies. In: 5th AESOP conference on sustainable food planning. 2013-10282013-10-29, Montpellier, FRA

Lascoumes P (2010) L'Éco-pouvoir: environnements et politiques. La découverte, Paris

Le Strat A (2008) Pour une eau du robinet de qualité. Un volet du développement soutenable dans une grande ville. Annales des Mines - Responsabilité et environnement 1(49):36-41

Liu M (1997) Fondement de la recherche-action. L'Harmattan, Paris

Petit S, Soulard CT (2015) Rencontres par-delà les frontières: l'analyse du partenariat chercheursacteurs dans le programme de recherche PSDR. In: Les chercheurs ignorants (eds) Les recherches-actions collaboratives. Une révolution de la connaissance. EHESP, Rennes, pp 93-100

Pinson D (1995) Générations immigrées et modes d'habiter. Entre repli communautaire et fusion transethnique Les Annales de la Recherche Urbaine 68-69:189-198

Raja S, Li Yin L et al (2010) Food environment, built environment, and women's BMI: evidence from Erie County, New York. J Plan Educ Res 29:444-460

Rey-Valette H, Chia E et al (2014) Comment analyser la gouvernance territoriale? Mise à l'épreuve d'une grille de lecture. Géographie, économie, société 16(1):65-89 
Rocha C (2001) Urban food security policy: the case of Belo Horizonte, Brazil. J Stud Food Soc $5(1): 36-47$

Shove E, Pantzar M, Watson M (2012) The dynamics of social practice: everyday life and how it changes. Sage, London

Soulard CT, Compagnone C, Lémery B (2007) La Recherche en partenariat: entre fiction et friction. Nat Sci Soc 15(1):13-22

Viljoen A, Wiskerke JS (2012) Sustainable food planning: evolving theory and practice. Wageningen Academic Pubication, Wageningen

Warde A (2005) Consumption and theories of practice. J Consum Cult 5(2):131-153

Yin L, Raja S et al (2013) Neighborhood for playing: using GPS, GIS, and accelerometry to delineate areas within which youth are physically active. Urban Stud 50(14):1-18

Open Access This chapter is licensed under the terms of the Creative Commons Attribution 4.0 International License (http://creativecommons.org/licenses/by/4.0/), which permits use, sharing, adaptation, distribution and reproduction in any medium or format, as long as you give appropriate credit to the original author(s) and the source, provide a link to the Creative Commons licence and indicate if changes were made.

The images or other third party material in this chapter are included in the chapter's Creative Commons licence, unless indicated otherwise in a credit line to the material. If material is not included in the chapter's Creative Commons licence and your intended use is not permitted by statutory regulation or exceeds the permitted use, you will need to obtain permission directly from the copyright holder. 